Грицевич, Юрій, і Левчук, Ірина. «Тематична група назв їжі, напоїв та кухонного начиння у фольклорних текстах із Західного Полісся». Лінгвостилістичні студіï, вип. 11, 2019, с. 34-43.

Hrytsevych, Yurii, and Levchuk, Iryna. "The Thematic Group of the Lexemes Denoting Foodstuff, Beverages and Kitchen Utensils in the Western Polissian Folklore Texts". Linguostylistic Studies, iss. 11, 2019, pp. 34-43.

УДК 811.161.2'282.2:[392.8:801.8(477.82)

https://doi.org/10.29038/2413-0923-2019-11-34-43

\title{
ТЕМАТИЧНА ГРУПА НАЗВ ЇЖІ, НАПОЇВ ТА КУХОННОГО НАЧИННЯ У ФОЛЬКЛОРНИХ ТЕКСТАХ ІЗ ЗАХІДНОГО ПОЛІССЯ
}

\author{
Юрій Грицевич, Ірина Левчук \\ Східноєвропейський національний університет імені Лесі Українки, \\ Луцьк, Україна
}

У статті на матеріалі текстів фольклору окреслено номінаційні процеси, проаналізовано склад, структурну організацію й семантику лексем на позначення їжі, напоїв та кухонного начиння в західнополіських говірках. 3'ясовано, що номінації продуктів харчування здебільшого мотивовані основним компонентом страви, смаком, кольором, розміром, формою, назвою свята, на яке призначено страву чи виріб тощо. Констатовано, що тексти фольклору обмежено відображають склад діалектної лексики. Усе розмаїття народних назв в уснопоетичних текстах просто й не може бути представлене з огляду на призначення й іншу специфіку самого фіксованого матеріалу.

Ключові слова: діалектна лексика, Західне Полісся, фольклорні тексти, номен, лексико-семантична група, назви їжі та напоїв, назви кухонного начиння.

\section{THE THEMATIC GROUP OF THE LEXEMES DENOTING FOODSTUFF, BEVERAGES AND KITCHEN UTENSILS IN THE WESTERN POLISSIAN FOLKLORE TEXTS Yurii Hrytsevych, Iryna Levchuk}

Lesya Ukrainka Eastern European National University, Lutsk, Ukraine

The richness of the Ukrainian dialectal lexicon provide multifaceted opportunities for the study of its composition structure, the system of organization, features of functioning and its areal handling. The article, drawing on the materials of the folklore texts, provides a detailed analysis of the nomination processes, composition, structural organization, and semantics of the lexemes denoting foodstuff, beverages, and kitchen utensils in the Western Polissian dialect.

The study has revealed that nominations of food are motivated mostly by the main ingredient of a dish, its taste, color, the holiday name for which the dish or product is intended, its shape, or purpose features, etc. Most of the detected lexemes are also commonly used in other Ukrainian language dialects. The nominations are described according to the lexical-semantic principle. In this article, 3 thematic subgroups (names of foodstuffs, names of beverages and names of kitchen utensils) are analyzed. A great variety of methods and techniques have been utilized to study the dialect vocabulary. The basic among them are the descriptive and analytical method (to systematize linguistic material and interpret the collected linguistic facts) and comparative-historical method (to find out the genesis of the

(c) Грицевич Ю., Левчук І., Східноєвропейський національний університет імені Лесі Українки, 2019.

Це стаття відкритого доступу на умовах СC BY-NC 4.0 
lexical units). The study has revealed that modern rapid changes in nutrition give rise to the archaization of the traditional words in the lexical groups under consideration.

The key findings of the research argue that the folklore texts reflect a limited proportion of the modern dialect vocabulary and. All the diversity of the folk vocabulary in the oral poetic texts cannot be represented in detail in the article due to the specific features of the selected material. The analyzed lexical content of the thematic groups of food, beverages, utensils contributes to the representation of the studied segment of the West Polissian dialect vocabulary in the Ukrainian continuum.

Key words: dialectical vocabulary, Western Polissia, folklore texts, nomen, lexicalsemantic group, names of foodstuffs and beverages, names of kitchen utensils.

Вступ. У складі лексичної системи говірок особливе місце посідає народна кулінарна номенклатура, адже харчування, як відомо, основна фізіологічна потреба людини, а національна кухня - визначальна ознака культури народу. «Увага до лексики говорів, - як зазначає П. Гриценко, загострена не лише у зв'язку з необхідністю забезпечити надійним матеріалом ті галузі мовознавства і суміжних наук, які безпосередньо пов'язані 3 реконструкцією давнішого стану матеріальної і духовної культури носіїв мови. При всій очевидності змін у словниковому складі мови лексична система зберігає такі архаїчні риси, які часто несуть більшу інформацію, ніж релікти інших структурних рівнів» (Гриценко, Моделювання 3).

Сучасна лінгвістика переживає, за влучним висловом З. Коцюби, «фольклорний бум». Матеріали різних фольклорних жанрів широко використовують у лінгвокультурологічних, етнолінгвістичних, лінгвосеміотичних дослідженнях 3 огляду на те, що фольклор - те джерело, яке дає змогу осягнути живу сутність національних традицій, зрозуміти етнічні особливості світосприйняття, мислення, спілкування (Коцюба 35). Пріоритетним у мовознавстві, на думку Н. Гуйванюк, залишається культурологічний аспект дослідження лексичного багатства говірок, оскільки відповідає проблемі «мова - мислення - культура», адже в говіркових системах чимало лексем із «культурним компонентом», у яких віддзеркалено реалії культури певного народу, що складають його самобутність, відрізняють від інших етносів, а отже, «українська етнолінгвістика розвивається в тісному зв'язку з діалектологією» (255).

Дослідження лексики українських говорів за різними тематичними групами видається актуальним з огляду на все ще недостатню емпіричну базу сучасної діалектної лексикології та лексикографії. П. Гриценко зауважує, що «сьогодні $\epsilon$ самоочевидною неоднакова повнота представлення лексики діалектної мови як за регіонами, ареалами побутування діалектної мови, так i набором тематичних, лексикосемантичних груп та повнотою відтворення елементів у межах цих об’єднань» («Українська» 12). Серед причин такого стану вивчення основного об'єкта діалектології науковець називає значну за обсягом територію поширення української діалектної мови, що унеможливлює їі 
докладне обстеження одним дослідником, навіть якщо він обирає одну тематичну групу. Тому лексику тієї самої тематичної групи в різних зонах поширення української мови, не покриваючи всього діалектного континууму, вивчають кілька дослідників (Гриценко, «Українська» 12).

Грунтовні дослідження тематичних груп «Назви їжі та напоїв» та «Назви кухонного начиння» здійснено на матеріалі буковинських (Борис), східнослобожанських (Волошинова), східностепових (Загнітко), східноподільських (Оскирко), східнополіських (Турчин), суміжних надсянсько-наддністрянських говірок (Різник) та ін. Назви продуктів харчування, страв та напоїв на матеріалі українських пам'яток XIV-XVII століття вивчав С. Яценко.

Мета статті - з'ясування репертуару номінативних одиниць та їхньої семантики в межах тематичної групи назв їжі, напоїв та кухонного начиння на матеріалі фахово записаних фольклорних текстів із Західного Полісся - ареалу старожитнього говору північного наріччя української мови.

Методи дослідження. Для досягнення задекларованої мети застосовано описово-аналітичний метод (систематизовано мовний матеріал та інтерпретовано зафіксовані у фольклорних текстах лінгвістичні факти). Використання елементів порівняльно-історичного методу уможливило з'ясування генези окремих лексичних одиниць.

Результати дослідження та дискусія. Назви страв у залученому для дослідження уснопоетичному матеріалі становлять розгалужену та багаторівневу систему.

Для реалізації семеми «їжа; продукти харчування» побутує гіперномен їедло - західнослов'янське запозичення, яке походженням сягає іє. *еd- «їсти» (Етимологічний 2: 325), пор.: «А в туй хатці в ліесі жив собіе зайчик. Ходив часто на польованне, старався на зиму їедла» (Котилася торба 97).

Відвідування гостей не обходиться без споживання їжі, частувань. Лексема беседа (широко засвідчена в текстах західнополіського фольклору в різних фонетико-словотвірних виявах, але обов'язково 3 наголосом на другому складі) вербалізує позначення гостювання на весіллі, хрестинах, а відповідно, спільного прийому їжі під час цих та інших обрядових церемоніалів, пор.: «Сватойку-голубойку, запиши беседойку, щоб ми пили, їли, безпечно сиділи» (Денисюк 94), «Цап и баран на вечеру нам. Щоб наша беседонька завше була веселенька» (Весільні обряди 66), «Сію мак, сію мак да й по городь́́ны, высёлая бысэ́донька у мэйі родыны» (Клімчук, Традыцыйнае 510), «Прыбудь, прыбудь, татуленьку, до мэнэ, есть у мэнэ бэсэдонька для тэбэ, есть у мэнэ міед, горіелка - нап'есся, есть у мэнэ постіель біела - выспісся» (Śpiewnik podlaski 53), пор. літ. бе́сіда «розмова з ким-небудь; доповідь; співбесіда» (Словник 1: 162).

Чільне місце посідає підгрупа «назви хліба», яку репрезентують слова: nana «дит. хліб», пор.: «Видно, шо Гапа пикла папy, бо ворота в тісті» (Аркушин, Сказав 63); булка «хлібина, паляниця», пор.: «Чого нас не 
вітаєте, бо хліба не маєте, не маєте. Біжіте до сусіда, позичте булку хліба» (Семенюк 168), пор. літ. булка «хліб з білого пшеничного борошна» (Словник 1: 253); бохонещь «хлібина, паляниця», пор.: «Выходь, выходь, да мы'й батыньку, з бохонцэм, Ужэ ж твое ріднэ дітятко з молодцэм» (Клімчук); палинка, пальонка, палінка «паляниця», пор.: «Сванєчка виїжджає із майна, із хатойки, із двора багатого, з квартою, з горілкою, з пшеничною палинкою» (Цехміструк 63), «Де були, де бували, Ще таке не видали, Скатерки шовковиї, Пальонки питльовиї, Бутельки з-под Гданська Сватанина панська» (Записала О. Степанчук), «Ой, ци нам буде хліба палінки, Хліба палінки, кварта горівки, Сирець біленький, хлібець м'якенький?» (Записала З. Давидюк), «Дєку, сванечку, дєку, За сер, за горилку, За пшеничну палінку» (Записала 3. Давидюк). Ад’єктив у словосполученні пальонки питльовиї мотивований тим, що мука змелена декілька разів, щоб пройшла через питель «пристрій для просіювання борошна»; питель запозичення з польської мови (Етимологічний 4: 378).

Номінативний ряд на позначення першої відрізаної від паляниці скибки групує мовні одиниці: окрушок, пор.: «Не йіж окрушка, бо полюбиш Андрушка» (Аркушин, Сказав 31) - похідне утворення від круг, пор. слц. okružok «шматочок (хліба)» (Етимологічний 4: 174); осошомок, пор.: «Йа шче Хомочка - зйім осошомочка» (Аркушин, Сказав 49); лобок, пор.: «Йіж лопка, шоб дівчата любили» (Аркушин, Сказав 49). Сему «шматок хліба» передають номени луста, лусточка, пор.: «Дай хлі́ба!»- «Поскачи́l ді́да». «Скачу́ скачу́ ді́да за лу́сточку хлі́ба, то скачко́м, то бочко́м пьірыд па́ном Пытручко́м» (Клімчук, Прыказкі 158), «Бо я з хаты нэ пусточкы, Ў мэнэ у возы тры лусточкы. Одна луста - для гостыны, А другая - для дэтыны, $A$ трэтяя ў мэнэ ў возы: Обідала пры дорозы» (Шепелевич 65), пор. псл. [lusta] «луска, шкірка, лушпина; скибка; шматок» $з$ давнішого *lousta, похідного від кореня іє. *lеu- «відділяти, відривати, відрізати» (Етимологічний 3: 311).

Лексема колач номінує «білий хліб особливої форми (круглої, подовгуватої)», «білий здобний хліб», «білий хліб із різною начинкою» та бере свій початок від псл. *kolačь «печений хліб круглої форми», що $€$ похідним утворенням від *kolo «коло». Слово мотивоване округлою формою печива, яке мало первісно обрядове значення (коло - символ щастя) (Етимологічний 2: 348), пор.: «Встрьчай мэнэ, матэнько, съ колачемъ» (Булгаковській 87), «Люлі, люлі, люлі, чужим діетям дулі, а Манюлі колачі, щоби спала вдень й вночі» (Котилася торба 20).

На позначення страви із запареного борошна (найчастіше гречаної муки) реєструємо номінацію па́риш, пор.: «Грішний париш сім раз вариш, сім раз солиш і без соли йіси» (Аркушин, Сказав 49), «Добра́вся (до горі́лкы), (та)бы́ Харть́lн до па́рышу» (Клімчук, Прыказкі 159). Осібно виокремлюємо прозоро мотивовану назву колотуха < псл. *koltiti «бити, стукати; змішувати; трясти» (Етимологічний 2: 523), яка може вживатися на позначення «1. страви, звареної на воді або молоці з розтертого в дрібні кульки борошна з водою; 2. страви з густо запареного розколоченого 
борошна і засмаченої шкварками» (Аркушин, Словник 218), пор. у фольклорному контексті: «Жніте, женчики наші, наваріт мати каші, якеї колотухі для мене молодухі, якеї пшеничнеї для мене величнеї» (Поліська дома 259).

Велику роль у раціоні поліщуків відіграє картопля. Зафіксована в текстах фольклору назва бараболя - видозміна назви німецької землі Brandenburg, через яку картопля поширювалася на схід (Етимологічний 1: 137), пор.: «Як зайшов я до діевчыны далі крыесло сіесты, поставілі бараболы нэчышчоный eсты» (Śpiewnik podlaski 145). Унаслідок субституції звука [ф] фіксуємо ще такі назви картоплі: картохлі, картохель (Котилася торба 81), (пор. нвн. Kartóffel (Етимологічний 2: 397)), пор.: «Мачуха насипала в торбу заміст круп - тертаку, що дрова рубают, заміст хліеба і картохель - камені поклала» (Котилася торба 101), «Медвіедь всьо ходит, за тиї картохління тьогає. Прийшов час, наросли картохлі. Лисиця накопала картохель і міела на ціелу зиму, а медвіедь ничого» (Котилася торба 81), «Тертак і камені обернуліся в крупи і картохлі, і так діевчинка зварила суп» (Котилася торба 101). На позначення необчищеної від шкірки картоплі в підляських уснопоетичних текстах простежено назву бараболи з лужпаками, пор.: «Зайшов я до девчинонькі, то й кажуть мні сісти, поставили бараболи з лужпаками їсти» (Ігнатюк 25), пор. псл. luspa < *lousp-a, похідне від кореня іє. *leu«відокремлювати, відділяти, відривати», до якого зводяться й псл. lupiti «лупити», luska «луска» (Етимологічний 3: 311).

У кулінарній номенклатурі західних поліщуків міцно закріпилося запозичення з польської мови шиирка «сало», пор.: «Подаруй-но, татойку, ще й свинку, Щоб ни було дотьону за шпирку» (Записала Г. Назарук), пор. етимологічно нез'ясовані п. ст. szpyrka, szperka (Етимологічний 6: 462).

Широкий спектр кулінарних реалій охоплює лексема каплун, яка в діалектному мовленні може реалізувати такі значення: 1. їжа, приготована з розтертої покришеної зеленої цибулі, засмачена олією та сіллю; 2. страва 3 листя капусти, каші та м'яса (вид голубців); 3. покришений хліб, змішаний із молоком або солодкою водою; 4. картопляний відвар, заправлений чорним перцем; 5. страва із сухарів з додаванням цибулі та олії; 6. булка з цукром, яку запивають молоком (Аркушин, Словник 209), пор. у фольклорному контексті: "Дала сыну каплун істы, а нывістцы сычовыцы» (Раговіч 308), «Молодому - каплунець тлустий, а старому качана гризти» (Цехміструк 257), пор. літ. каплун «кастрований півень, якого відгодовують на м'ясо» (Словник 4: 95), пор. польські kapłun «суп 3 води, хліба, часнику, солі, масла і яєць», kapłon «суп з води і хліба або булки з додаванням солі, кмину, рідко масла або смальцю; тетеря (страва)» не цілком ясні; назва могла виникнути як іронічне позначення бідної, непоживної страви (на відміну від високоякісної їжі 3 каплунів кастрованих півнів) (Етимологічний 2: 374). 
3-поміж лексики на позначення їжі чільне місце посідає угруповання слів - назви обрядових страв: сэрп «ритуальний хлібець у вигляді серпа, який пекли на свято Благовіщення (7 квітня)» пор.: «Буську, буську, на тобі cырna, дай мыні жыта снопа» (Климчук 210); борона «ритуальна булочка у вигляді борони, яку пекли на Благовіщення», пор.: «Буську, буську, на тобі борону, дай мыні жыта сторону» (Климчук 210); лапка «хлібець із зображенням ноги лелеки», пор.: «Бусныку, бусныку, во дэ твоя лапка! Прылыты, ухопы и назад полыты!» (Полесский 207); голёпа, галепа «хлібець із зображенням ноги лелеки; булочка із видавленою фігурою лелеки», пор.: «Бусля, бусля, на тэбэ голёпу, а мни дай жита копу» (Полесский 208), "Буську, буську на тобі галепу, дай мыні жыта копу» (Климчук 210); сир «печений сир як обрядова страва на весіллі», пор.: «До сира спуваєте - талірки не маєте! Матюнки просіте або в місто біжіте» (Денисюк 151), «В нас послуги нема, щоб нам сирець принесла. В нас послуга на ріці, в нас сирещь на печі. Віте гроші пощитайте, а на сирець почекайте» (Денисюк 151), «Ой, поки сваха Дунай перейшла, взяла водиця сирець понесла» (Денисюк 146). Відомий український фольклорист, професор I. Денисюк зауважував: «Трикратне функціонування обрядового сиру - у пиріжках-запрошеннях, як «великоє даро» свахи і як мандричка, яку дає молода, а крає дружко, підтверджує думку дослідників, що сир у поліському весіллі є пракороваєм» (17).

Ознаку «розсипчастий» у діалектному мовленні реалізує лексема сопкий - похідне утворення від псл. $s ъ p-\left(<{ }^{*} s u ̆ p-\right)$, відображеного в п. ст. sep «данина зерном», др. съпъ «насип, вал, гора», стсл. съпж «сиплю» i пов'язаного чергуванням голосних із syp- (*sūp-) «сипати» (Етимологічний 5: 355), пор.: «Коровайночкы німы Грэцькую луску йілы. Грэцькая луска сопка, Да й залыпла йім глотка», пор. фіксацію Г. Аркушина сопк'i, -a, -e «добра на смак, розвариста, не водяниста (про картоплю)» (Аркушин, Словник 517). До різновиду загальних назв можна віднести ад'єктив жешкі «гарячий», похідний від псл. žegg, *žьgg, žegti < *gegti «горіти; палити, випалювати» (Етимологічний 2: 191) та мотивований тактильними відчуттями на позначення їжі, яка зазнала термічної обробки (варіння, тушіння, смаження, запікання і т. п.), пор.: «Діед за той час наварив супу. Дмухає, дмухає, а суп жешкі» (Котилася торба 93).

Лексичне угруповання з семою «смачити страву чимось жирним» увиразнюють структури шмаровати, пор.: «Ох, сваничко наша, ни шмарована каша, будете шмаровати - будемо поїдати» («Весільні» 170), пор. літ. шмарувати «змащувати що-небудь (поверхні тертя механізмів і деталей машин, взуття і т. ін.) мазутом чи дьогтем» (Словник 11:498); затлустіти, пор.: «Їжте, свахи, капусту, наша капуста тлуста, комара задушилі, капусту затлустілі» (Ой були 104) - запозичення з польської мови (tłusty «жирний; гладкий, повний, товстий; масний» (Етимологічний 5: 585)). 
Лексема ягли входить до складу фразеологізмів наварити ягли «нічого не приготувати з їжі», їсти ягли «нічого не їсти», пор.: «Наварила йагли да й спати голодни лягли» (Аркушин, Сказав 49), "Будиш йісти йагли, ті шу биз вичери спати лягли» (Аркушин, Сказав 49), пор. псл. jagla, jaglo, jaglъ «сильна, (-е, -ий)»; та, що дає силу (про кашу), є віддієслівним прикметником; пл. jagła «просо; просина», р.ст. ягла́ «вид каші» (Етимологічний 6: 533).

Серед назв напоїв зафіксовано номен жур - «вівсяний кисіль», пор.: «Ны шуру, ны з буру, дай, бабо, журу» (Міхайлаў 82), пор. польське žur «кисла юшка» (Етимологічний 2: 210).

До складу назв кухонного приладдя входять номени: квастка «невеличка бочка (діжечка) для зберігання солоного сиру», пор.: «Йакий батько, такий син - виносили з квастки сир» (Аркушин, Сказав 29); вирцюх «товкачик розтовкувати варену картоплю», пор.: «Що музиці дати, що ни хоче грати - ци гороху, ци бобу, ци вирџюха по лобу» (Семенюк 94), пор. псл. *v'rrtěti (Етимологічний 1: 360); рукавець «торбинка зі скошеною нижньою частиною для віддавлювання сиру», пор.: «На дубу на вершечку, там сирець у рукавечку. Iдіте, заберіте та й собі поділіте» (Денисюк 144), пор. літ. рукав «1. частина одягу, що покриває руку (від плеча до кисті або коротше); 2. водяний потік, що відійшов у бік від головного русла; відгалуження ріки» (Словник 8: 905); порція «склянка місткістю 100 мл», пор.: «Порцыя скыль?» - «3 Ростова» - «Паспорт е?» - «Ныма». - «Тут тобі тюрма: за здоров'е вашэ, в горло нашэ» (Клімчук, Прыказкі 164), пор. літ. порція «певна кількість харчового продукту, страви, призначена для споживання однією особою за один раз» (Словник 7: 300).

Висновки та перспективи досліджень. Отже, проаналізоване лексичне наповнення тематичної групи назв їжі, напоїв та кухонного начиння сприяє репрезентації досліджуваного сегмента західнополіської діалектної лексики в загальноукраїнському континуумі. Основний фонд аналізованих слів - континуанти праслов'янських утворень - належить до найдавніших шарів української мови. Частина лексем потрапила до західнополіських говірок через посередництво польської мови. Ряд назв мають переважно фонетичні варіанти та незначні словотвірні модифікації.

Номінації продуктів харчування здебільшого мотивовані основним компонентом страви, смаком, кольором, розміром, формою, назвою свята, на яке призначено страву чи виріб тощо. Констатовано, що тексти фольклору обмежено відображають склад діалектної лексики. Усе розмаїття народних назв в уснопоетичних текстах просто й не може бути представлене 3 огляду на призначення й іншу специфіку самого фіксованого матеріалу.

Проаналізована лексика становить інтерес також як джерело для етнолінгвістичних досліджень. Перспективу подальших студій убачаємо у вивченні інших лексико-семантичних груп діалектної лексики Західного Полісся на матеріалі фольклорних текстів. 


\section{Список використаних джерел}

Аркушин, Григорій. Сказав, як два зв'язав: Народні вислови та загадки із Західного Полісся $і$ західної частини Волині. Люблін; Луцьк: Polskie Towarzystwo Ludoznawcze, 2003.

Аркушин, Григорій. Словник західнополіських говірок. 2-ге вид. Луцьк, 2016.

Булгаковскій, Д. «Пинчуки». Этнографическій сборникъ. Пъсни, загадки, пословицы, обряды, примъты, предразсудки, повърья, суевърья и местный словарь. Т. XIII, вып. 3. Санктъ-Петербургъ, 1890.

«Весільні пісні села Воронки у записах Віктора Ковальчука», транскрипції Людмили Гапон. Етнокультурна спадщина Полісся, вип. VII, 2008, с. 169-78.

Весільні обряди Рівненщини. Фольклорно-етнографічні записи XIX - початку XX сm. Рівне: Волинські обереги, 2004.

Денисюк, Іван. Пісні з-над берегів Турського озера: пісні і коментарі. Луцьк: Надстир'я, 2004.

Етимологічний словник украӥнської мови, під ред. О. С. Мельничука. В 7 т. Київ: Наукова думка, 1982-2012.

Записала 3. Давидюк у с. Залухово Ратнівського району Волинської області від Ю. Колос (1994 p.).

Записала Г. Назарук у с. Видраниця Ратнівського району Волинської області від В. Назарук.

Записала О. Степанчук у с. Хотешів Камінь-Каширського району Волинської області від О. Баран 1935 р.н., неписьменна (11 липня 1990 р.).

Ігнатюк, Іван. Фольклорні записи з Підляшшя. Люблін, 2003.

Клімчук, Фёдар. «А в нашого свата... (прыпывкы з вёскі Сіманавічы Брэсцкай вобласці)». Діалектологічні студії. 3. Пам'яті Ярослави Закревської. Львів, 2003, с. 494-516.

Клімчук, Фёдар. «Прыказкі і прымаўкі 3 вёскі Сіманавічы Драгічынскага раёна». Беларуская дыялекталогія. Матэрыялы і даследаванні, вып. 3, 2014, с. 157-68.

Клімчук, Фёдар. Традыцыйнае вяселле вёскі Сіманавічы. URL: http://zagorodde.na.by/folk.html.

Климчук, Ф. «Песенная традиция западнополесского села Симоновичи». Славянский и балканский фольклор: Генезис. Архаика. Традищии. Москва: Наука, 1978, с. 190218.

Котилася торба з високого горба: дитячий фольклор із Північного Підляшшя. Більськ на Підляшші, 2011.

Міхайлаў, П. «З лексікі нашай вёскі». Жывое наша слова. Мінск: Беларуская навука, 2001, c. 116-25.

Ой були ми на весіллі. Весільні пісні Західного Полісся з голосу Уляни Кот, упоряд. Кузьми Смаля. Львів: Кобзар, 2012.

Полесский этнолингвистический сборник: материалы и исследования, отв. ред. Н. И. Толстой. Москва: Наука, 1983.

Поліська дома, упоряд. Віктор Давидюк, вип. III. Луцьк: ПВД «Твердиня», 2008.

Раговіч, Уладзімір. Песенны фальклор Палесся. Т. 1. Песні святочнага календара. Мінск: Чатыры чвэрці, 2001.

Семенюк, Лариса. Народна обрядова творчість Шацького поозер'я. Луцьк: ВНУ імені Лесі Українки, 2012.

Словник української мови, за ред. І. К. Білодіда. В 11 т. Київ: Наукова думка, 1970-1980.

Цехміструк, Юрій. Народні пісні Волині: Фонографічні записи 1936-1937 років. Львів; Рівне, 2006.

Шепелевич, Василий. Песни деревни Ковнятин Пинского района. Пинск: Паляшук, 2014. Śpiewnik podlaski, pod red. Doroteusza Fionika. Białystok: Związek Białoruski w Rzeczypospolitej Polskiej, 1998. 


\section{Sources}

Arkushyn, Hryhorii. Skazav, yak dva zviazav: Narodni vyslovy ta zahadky iz Zakhidnoho Polissia i zakhidnoi chastyny Volyni. Liublin; Lutsk: Polskie Towarzystwo Ludoznawcze, 2003.

Arkushyn, Hryhorii. Slovnyk zakhidnopoliskykh hovirok. $2^{\text {nd }}$ ed. Lutsk, 2016.

Bulgakovskij, D. "Pinchuki". Jetnograficheskij sbornikŭ. Pěsni, zagadki, poslovicy, obrjady, priměty, predrazsudki, pověr'ja, suevěr'ja i mestnyj slovar'. T. XIII, vyp. 3. Sanktŭ Peterburgŭ, 1890.

"Vesilni pisni sela Voronky u zapysakh Viktora Kovalchuka". Etnokulturna spadshchyna Polissia, iss. VII, 2008, pp. 169-78.

Vesilni obriady Rivnenshchyny. Folklorno-etnohrafichni zapysy XIX - pochatku XX st. Rivne: Volynski oberehy, 2004.

Denysiuk, Ivan. Pisni z-nad berehiv Turskoho ozera: pisni i komentari. Lutsk: Nadstyria, 2004.

Etymolohichnyi slovnyk ukrainskoi movy, edited by O. S. Melnychuk. 7 vols. Kyiv: Naukova dumka, 1982-2012.

Zapysala Z. Davydiuk u s. Zalukhovo Ratnivskoho raionu Volynskoi oblasti vid Yu. Kolos.

Zapysala H. Nazaruk u s. Vydranytsia Ratnivskoho raionu Volynskoi oblasti vid V. Nazaruk.

Zapysala O. Stepanchuk u s. Khoteshiv Kamin-Kashyrskoho raionu Volynskoi oblasti vid O. Baran 1935 r.n., nepysmenna.

Ihnatiuk, Ivan. Folklorni zapysy z Pidliashshia. Liublin, 2003.

Klimchuk, Fiodar. "A v nashoho svata... (prypyvkyz vioski Simanavichy Brestskaj voblastsi)". Dialektolohichni studii. 3. Pamiati Yaroslavy Zakrevskoi. Lviv, 2003, pp. 494-516.

Klimchuk, Fiodar. "Prykazki i prymaŭki z vioski Simanavichy Drahichynskaha rajona". Belaruskaia dyjalektalohiia. Materyjaly i dasledavanni, iss. 3, 2014, pp. 157-68.

Klimchuk, Fiodar. Tradycyinae viaselle vioski Simanavichy. zagorodde.na.by/folk.html.

Klimchuk, Fiodar. "Pesennaja tradicija zapadnopolesskogo sela Simonovichi". Slavjanskij $i$ balkanskij fol'klor: Genezis. Arhaika. Tradicii. Moskva: Nauka, 1978, pp. 190-218.

Kotylasia torba $z$ vysokoho horba: dytiachyi folklor iz Pivnichnoho Pidliashshia. Bilsk na Pidliashshi, 2011.

Mikhailaŭ, P. “Z leksiki nashai vioski”. Zhyvoe nasha slova. Minsk: Belaruskaia navuka, 2001, pp. 116-125.

Oi buly my na vesilli. Vesilni pisni Zakhidnoho Polissia z holosu Uliany Kot, edited by Kuzma Smal. Lviv: Kobzar, 2012.

Polesskij jetnolingvisticheskij sbornik: materialy i issledovanija, edited by N. I. Tolstoj. Moskva: Nauka, 1983.

Poliska doma, edited by Viktor Davydiuk, vyp. III. Lutsk: PVD “Tverdynia”, 2008.

Rahovich, Uladzimir. Pesenny falklor Palessia. T. 1. Pesni sviatochnaha kalendara. Minsk: Chatyry chverci, 2001.

Cemeniuk, Larysa. Narodna obriadova tvorchist Shatskoho poozeria. Lutsk: VNU imeni Lesi Ukrainky, 2012.

Slovnyk ukrainskoi movy, edited by I. K. Bilodid. 11 vols. Kyiv: Naukova dumka, 1970-1980.

Tsekhmistruk, Yurii. Narodni pisni Volyni: Fonohrafichni zapysy 1936-1937 rokiv. Lviv; Rivne, 2006.

Śpiewnik podlaski, pod red. Doroteusza Fionika. Białystok: Związek Białoruski w Rzeczypospolitej Polskiej, 1998.

\section{Список використаної літератури}

Борис, Людмила. Динаміка тематичної групи лексики їжі та напоїв у буковинських говірках. Автореф. дис. ...канд. філол. наук: 10.02.01. Чернівці, 2015.

Волошинова, Марина. Динаміка традиційної предметної лексики в українських східнослобожанських говірках. Автореф. дис. ...канд. філол. наук: 10.02.01. Луганськ, 2014. 
Гриценко, Павло. Моделювання системи діалектної лексики. Київ: Наукова думка, 1984. Гриценко, Павло. «Українська діалектна лексика: реальність і опис (деякі аспекти)». Діалектна лексика: лексикологічний, лексикографічний, лінгвогеографічний аспекти: матеріали доповідей Міжнародної наукової конференції. Глухів: РВВ ГдПУ, 2005, с. 5-23.

Гуйванюк, Ніна. Слово - Речення - Текст. Чернівці: Чернівецький національний університет, 2009.

Загнітко, Надія. Назви їжі, напоїв у східностепових говірках Донеччини. Автореф. дис. ...канд. філол. наук: 10.02.01. Донецьк, 2011.

Коцюба, Зоряна. «Паремії як об’єкт етнолінгвопсихологічного дослідження». Мовознавство, № 2, 2009, с. 34-47.

Оскирко, Олексій. Назви їжі та напоїв у східноподільських говірках. Автореф. дис. ...канд. філол. наук: 10.02.01. Умань, 2018.

Різник, Віра. Назви їжі та кухонного начиння в говірках надсянсько-наддністрянського суміжжя. Автореф. дис. ...канд. філол. наук: 10.02.01. Львів, 2017.

Турчин, Євгенія. Назви їжі на Східному Поліссі. Львів: Українська академія друкарства, 2012.

Яценко, Сергій. Назви продуктів харчування, страв і напоїв в украӥнській мові XIV-XVII століть. Автореф. дис. ...канд. філол. наук: 10.02.01. Київ, 2009.

\section{References}

Boris, Liudmyla. The dynamic content of the thematic lexical group of food and beverages in Bukovyna patois. PhD Thesis Abstract. Chernivtsi, 2015.

Voloshynova, Maryna. Dynamics of traditional subject vocabulary in Ukrainian East Slobozhanshchina dialects. PhD Thesis Abstract. Luhansk, 2014.

Hrytsenko, Pavlo. Modeliuvannia systemy dialektnoi leksyky. Kyiv: Naukova dumka, 1984.

Hrytsenko, Pavlo. "Ukrainska dialektna leksyka: realnist i opys (deiaki aspekty)". Dialektna leksyka: leksykolohichnyi, leksykohrafichnyi, linhvoheohrafichnyi aspekty: materialy dopovidei Mizhnarodnoi naukovoi konferentsii. Hlukhiv: RVV HDPU, 2005, pp. 5-23.

Huivaniuk, Nina. Slovo - Rechennia - Tekst. Chernivtsi: Chernivetskyi natsionalnyi universytet, 2009.

Zahnitko, Nadiia. Names of Food and Drinks in Eastern Steppe Dialects of the Donetsk region. PhD Thesis Abstract. Donetsk, 2011.

Kotsiuba, Zoriana. "Paroemas as an Object of the Ethnolinguopsychological Research". Movoznavstvo, no. 2, 2009, pp. 34-47.

Oskyrko, Oleksii. Food and drinks nominations in the Eastern Podillia dialects. PhD Thesis Abstract. Uman, 2018.

Riznyk, Vira. The names of foodstuffs and kitchen utensils in the Ukrainian dialects of the SanDniester region. PhD Thesis Abstract. Lviv, 2017.

Turchyn, Yevheniia. Nazvy yizhi na Skhidnomu Polissi. Lviv: Ukrainska akademiia drukarstva, 2012.

Yatsenko, Serhii. The names of food products, dishes and beverages in the Ukrainian language in the XIV-XVII centuries. PhD Thesis Abstract. Kyiv, 2009. 